\title{
Effect of Organic Acids and Prebiotics on Bone Quality in Laying Hens Fed Diets with Two Levels of Calcium and Phosphorus
}

\author{
Sylwester Świątkiewicz, Jerzy Koreleski, Anna Arczewska \\ National Research Institute of Animal Science, Department of Animal Nutrition \\ and Feed Science, Balice, Poland \\ Received July 8, 2009 \\ Accepted October 21, 2009
}

\begin{abstract}
In an experiment conducted on caged Bovans Brown hens, the effect of diet supplementation using organic acids and prebiotic fructans on the biomechanical and geometrical indicators of the tibia and femur bones was evaluated. At 25 weeks of age, layers were randomly assigned to 14 experimental groups, each comprising 6 hens kept in individual cages. A $2 \times 7$ factorial arrangement, with two dietary levels of calcium and phosphorus (normal $-37.0 \mathrm{~g} \mathrm{Ca} / \mathrm{kg}, 6.5 \mathrm{~g}$ $\mathrm{P} / \mathrm{kg}$, and reduced $-32.5 \mathrm{~g} \mathrm{Ca} / \mathrm{kg}, 6.0 \mathrm{~g} \mathrm{P} / \mathrm{kg}$ ), and with diets supplemented by selected additives (none; inulin, $7.5 \mathrm{~g} / \mathrm{kg}$; oligofructose, $7.5 \mathrm{~g} / \mathrm{kg}$; short chain fatty acids (SCFA), $5.0 \mathrm{~g} / \mathrm{kg}$; medium chain fatty acid (MCFA), $2.5 \mathrm{~g} / \mathrm{kg}$; SCFA, $3.0 \mathrm{~g} / \mathrm{kg}+$ MCFA, $2.0 \mathrm{~g} / \mathrm{kg}$; inulin, $3.0 \mathrm{~g} / \mathrm{kg}+\mathrm{SCFA}$, $5.0 \mathrm{~g} / \mathrm{kg}$ ) was used. The experiment was conducted for 45 weeks and concluded when the hens were 70 weeks old.

At 70 weeks of age, reducing the dietary levels of $\mathrm{Ca}$ and $\mathrm{P}$ had decreased the bone breaking strength by $8.9 \%(P \leq 0.001)$ and the yielding load by $5.6 \%(P \leq 0.05)$. A similar tendency for bone breaking strength $(P \leq 0.05)$ and stiffness $(P \leq 0.05)$ was found in the femur bones. The diet with a lower level of $\mathrm{Ca}$ and $\mathrm{P}$ negatively affected the geometrical indicators of the bones such as cortex thickness $(P \leq 0.05)$ and cross section area $(P \leq 0.05)$, but had no effect on bone weight and length. Hens fed diets supplemented with oligofructose, MCFA, SCFA + MCFA or inulin + SCFA displayed a significantly higher bone breaking strength and yield load in the tibia bone than that of the control group. In the case of femurs, a positive influence of MCFA or simultaneous addition of inulin + SCFA on bone breaking strength was found. The additives had no significant effects on the geometrical indicators of either bone. It was concluded that selected feed additives which lower the $\mathrm{pH}$ of the diet and intestinal content can beneficially affect the biomechanical indicators of the bones of high-productive laying hens.
\end{abstract}

Laying hens, bone quality, calcium, organic acids, prebiotic fructans

Symptoms of osteoporosis are often observed in modern flocks of high-productive layers, especially in the second part of the laying cycle. Osteoporosis can be defined as a decrease in the fully mineralized structural bone in which $\mathrm{Ca}$ is mobilized from the bone in order to contribute to eggshell formation (Whitehead and Fleming 2000). The condition leads to increased bone fragility and susceptibility to fracture. The consequences of this syndrome, also known as 'cage layer fatigue', i.e., poor bone quality, weakness, deformities and breakage, spinal bone collapse and paralysis, can be an important welfare problem, causing acute and chronic pain and distress to the birds (Webster 2004). In the United Kingdom, it was found that, in the end phase of lay, $29 \%$ of caged hens had sustained one or more broken bones during their lifetime (Gregory and Wilkins 1989). A study conducted by McCoy et al. (1996) attributed 35\% of mortality in commercial caged laying hens to osteoporosis. Bone breakage is also a serious problem during the catching and transport of hens prior to slaughter, and during processing, which reduces the marketability of spent caged layers (Gregory and Wilkins 1989). Results of the study carried out by Jendral et al. (2008) indicate that hens caged in conventional cages, where the opportunity for movement and load-bearing exercises is limited, are particularly vulnerable to osteoporosis, exhibiting lower tibia and femur mineral density, bone mass, cortical bone area and mass and bone

Address for correspondence:

Doc. dr hab. Sylwester Świątkiewicz

National Research Institute of Animal Science

Department of Animal Nutrition and Feed Science

ul. Krakowska 1, 32-083 Balice, Poland
Phone: +48666081343

Fax: +48 122856733

E-mail: sylwester.swiatkiewicz@izoo.krakow.pl

http://www.vfu.cz/acta-vet/actavet.htm 
breaking strength than those kept in furnished colony cages, or cages modified with a nest box and perch.

Optimization of nutrition is one of the strategies for prevention of osteoporosis in hens. Because of the high demand for $\mathrm{Ca}$ in highly producing layers, the supply of an adequate amount of this macroelement in the diet is the most important nutritional factor influencing bone quality. Use of particulate limestone, as compared to fine particle $\mathrm{CaCO}_{3}$, as a source of $\mathrm{Ca}$ for hens was of benefit to bone strength and structure (Koreleski and Świątkiewicz 2004; Fleming 2008). In our earlier experiment, supplementation of the diet with 25-hydroxycholecalciferol, active metabolite of vitamin $\mathrm{D}_{3}\left(25-\mathrm{OH}-\mathrm{D}_{3}\right)$, which is necessary for the hen's proper Ca metabolism, was also shown to have a positive effect on selected mechanical properties of tibia bones (Świątkiewicz and Koreleski 2005).

The results of several studies carried out on rats have indicated that by lowering intestinal $\mathrm{pH}$, such additives as organic acids or prebiotic fructans (inulin, oligofructose) had a beneficial effect on Ca absorption (Lutz and Scharrer 1991; Delzenne et al. 1995; Ohta et al. 1995; Morohashi et al. 1998; Demigne et al. 2008), bone mineralization (Roberfroid et al. 2002; Kruger et al. 2003; Zafar et al. 2004; Nzeusseu et al. 2006; Demigne et al. 2008) and bone architecture measured as the femoral bone volume (Takahara et al. 2000). Sacakli et al. (2006) indicated that the addition of short chain organic acids (lactic +

Table 1. Composition of experimental diets in $\mathrm{g} / \mathrm{kg}$

\begin{tabular}{|l|c|c|}
\hline Ingredients & Control & $\begin{array}{c}\text { Reduced level } \\
\text { of Ca and P }\end{array}$ \\
\hline Maize & 514.2 & 539.2 \\
\hline Wheat & 120.0 & 120.0 \\
\hline Soybean oil meal & 236.0 & 230.0 \\
\hline Rapeseed oil & 14.0 & 7.0 \\
\hline Limestone & 94.0 & 84.0 \\
\hline Monocalcium phosphate & 12.5 & 10.5 \\
\hline NaCl & 3.0 & 3.0 \\
\hline DL-Methionine & 1.3 & 1.3 \\
\hline Vitamin-mineral premix ${ }^{1}$ & 5.0 & 5.0 \\
\hline Calculated nutrient content ${ }^{2}:$ & 170 & 170 \\
\hline Crude protein & 11.6 & 11.6 \\
\hline Metabolisable energy ${ }^{3}, \mathrm{MJ} / \mathrm{kg}$ & 8.2 & 8.2 \\
\hline Lys & 3.9 & 3.9 \\
\hline Met & 37.0 & 32.5 \\
\hline Ca & 6.5 & 6.0 \\
\hline P & 4.0 & 3.4 \\
\hline P available & 39.0 & 32.5 \\
\hline Analyzed: & 6.6 & 6.0 \\
\hline Ca & \multicolumn{2}{|c|}{} \\
\hline P & \multicolumn{2}{|c|}{} \\
\hline
\end{tabular}

${ }^{1}$ Premix provided per $1 \mathrm{~kg}$ of diet: vitamin A, 10,000 IU; vitamin $\mathrm{D}_{3}$, 3,000 IU; vitamin E, $50 \mathrm{IU}$; vitamin $\mathrm{K}_{3}, 2 \mathrm{mg}$; vitamin $\mathrm{B}_{1}, 1 \mathrm{mg}$; vitamin $\mathrm{B}_{2}, 4 \mathrm{mg}$; vitamin $\mathrm{B}_{6}, 1.5 \mathrm{mg}$; vitamin $\mathrm{B}_{12}, 0.01 \mathrm{mg}$; Ca-pantotenate, 8 $\mathrm{mg}$; niacin, $25 \mathrm{mg}$; biotin, $0.1 \mathrm{mg}$; folic acid, $0.5 \mathrm{mg}$; choline chloride, $250 \mathrm{mg}$; manganese, $100 \mathrm{mg}$; zinc, $50 \mathrm{mg}$; iron, $50 \mathrm{mg}$; copper, $8 \mathrm{mg}$; iodine, $0.8 \mathrm{mg}$; selenium, $0.2 \mathrm{mg}$, cobalt, $0.2 \mathrm{mg}$.

${ }^{2}$ Calculated from tables of feed composition on the basis of component nutrient content.

${ }^{3}$ According to the Janssen (1989) as a sum of ME content of feed components calculated on the basis of nutrient content. formic acid) to the diet for quail improved utilization of dietary phosphorus and increased the content of crude ash in tibia bones. Inulin or organic acids added to the diet for broilers increased the length of intestinal villus (Rehman et al. 2007; Senkoylu et al. 2007), which might stimulate the absorption of minerals.

The aim of the experiment was to study the effect on the biomechanical and geometrical properties of tibia and femur bones when short (SCFA), or medium chain fatty acids (MCFA), or prebiotic fructans with different lengths of chain (inulin or oligofructose) are added to the layer's diet at different levels of $\mathrm{Ca}$ and $\mathrm{P}$.

\section{Materials and Methods}

The Local Krakow Ethics Committee for Animal Experiments gave its approval to all the experimental procedures relating to the use of live animals. Eighty-four, 18-week-old Bovans Brown hens, obtained from a commercial source, were placed in individual cages, on a wire-mesh floor under controlled climate conditions in the poultry house at the Experimental Station of the National Research 
Institute of Animal Production in Balice, Poland. The cage dimensions were $40 \times 40 \mathrm{~cm}$, equalling to $1600 \mathrm{~cm}^{2}$ of total floor space. During the pre-experimental period, up to the $25^{\text {th }}$ week of the hens' age, a commercial laying hen diet was offered for ad libitum consumption (170 g crude protein $/ \mathrm{kg}, 11.3 \mathrm{MJl} / \mathrm{kg} \mathrm{AME}, 37.0 \mathrm{~g} \mathrm{Ca} / \mathrm{kg}$ and $3.8 \mathrm{~g}$ available $\mathrm{P} / \mathrm{kg}$ ).

At 25 weeks of age, the hens were randomly assigned to one of 14 experimental treatments comprising 6 individually caged layers for each treatment. During the experiment, the hens were provided with water and feed ad libitum, and were exposed to a 14 L:10 D lighting schedule with the light intensity of 10 lux.

A $2 \times 7$ factorial arrangement, with two dietary levels of $\mathrm{Ca}$ and $\mathrm{P}$, and with the diets being supplemented with experimental additives, was used. The basal experimental diets (Table 1) contained normal (37.0 and $6.5 \mathrm{~g} / \mathrm{kg}$ ) or lowered $(32.5$ and $6.0 \mathrm{~g} / \mathrm{kg}$ ) levels of $\mathrm{Ca}$ and $\mathrm{P}$, respectively. These diets were either unsupplemented or supplemented with additives as follows (per $\mathrm{kg}$ of diet): $7.5 \mathrm{~g}$ inulin (Beneo ${ }^{\mathrm{TM}}$ IPS, Orafti, Belgium), $7.5 \mathrm{~g}$ oligofructose (Beneo ${ }^{\mathrm{TM}}$ OPS, Orafti, Belgium), 5.0 g SCFA (2.0, 1.5 and $1.5 \mathrm{~g}$ of formic, propionic and acetic acid, respectively), $2.5 \mathrm{~g}$ MCFA (1.25 g of caproic and $1.25 \mathrm{~g}$ of capric acid), $3.0 \mathrm{~g}$ SCFA $+2.0 \mathrm{~g}$ MCFA or $7.5 \mathrm{~g}$ inulin + 5.0 g SCFA.

The experimental diets were fed from 25 to 70 weeks of age. The nutrient content of the diets was calculated on the basis of the chemical composition of raw feedstuffs, and metabolizable energy value in line with equations from the European Tables (Janssen 1989). Samples of feed components were analyzed using standard methods (AOAC 1990) for moisture (method 930.15), crude protein (984.13), crude fat (920.39) and ash (942.05). Amino acids were analyzed in acid hydrolysates, after initial performic acid oxidation of sulphur amino acids and after alkaline hydrolysis of tryptophan (AOAC 1990; method 982.30). The Ca content of ingredients and the diets was analyzed by flame atomic absorption spectrophotometry (AOAC 1990; method 968.08) and the total P content by colorimetry using the molybdo-vanadate method (AOAC 1990; method 965.17).

At the end of the experiment all the hens were sacrificed by cervical dislocation. The tibia and femur from the right leg were collected, cleaned of soft tissues, weighed and frozen $\left(-20{ }^{\circ} \mathrm{C}\right)$ until analysis. Biomechanical properties of the bones were measured by means of three point bending test using an Instron 5542 testing machine (constant speed of the crosshead $-10 \mathrm{~mm} / \mathrm{min}$ and distance between supports $-50 \mathrm{~mm}$ ). Bone breaking strength and yield load were measured as a graphical record from post deformation curves. Stiffness in elastic conditions was calculated as the yield load/elastic deformation ratio.

Tibia length, cortex thickness, external and internal diameters (for cross-section area calculations) were measured in the breaking place using an electronic slide caliper. The cross-section area was calculated from the equation: $3.14(\mathrm{HB}-\mathrm{hb}) / 4$, where $\mathrm{H}=$ external, vertical diameter; $\mathrm{B}=$ external, horizontal diameter; $\mathrm{h}=\mathrm{internal}$, vertical diameter; and $\mathrm{b}=$ internal, horizontal diameter.

The data were statistically analyzed using a completely randomized design in accordance with the GLM procedure of Statistica 5.0 (Statsoft, Inc., Tulsa, OK). All the data were analyzed using two-way ANOVA. When significant differences in treatment means were detected by ANOVA, Duncan's multiple range test was applied to separate means. Significance was considered at $P \leq 0.05$.

\section{Results and Discussion}

The bone breaking strength of tibias and femurs of Bovans Brown hens obtained in this study (160 and $166 \mathrm{~N}$ averaged across all dietary treatments) were lower than the values obtained in our earlier experiments with Hy-Line Brown and Lohman Brown hens of a similar age (Świątkiewicz and Koreleski 2005; 2007). These differences may indicate the influence of genetic selection on the biomechanical indicators of bones. Similarly, Newman and Leeson (1999) reported differences in bone quality among four strains of layers. They found the highest value of tibia breaking strength and cross sectional area for Hy-Line and the lowest for DeKalb hens. Riczu et al. (2004) noticed that the bone breaking strengths of the modern brown-egg strain (Shaver 579) were greater by $22 \%$ (femur) and 18\% (humerus) than in the white-egg strain hens (Shaver 2000). The effects of the hen's genetic line on bone quality were also found by Rennie et al. (1997) who reported that highly productive modern strain layers (Hisex Brown) were more susceptible to osteoporosis than the older J-line Brown Leghorn strain. Clark et al. (2008) found genetic line differences in fracture incidence in layers at 65 weeks of age and concluded that these differences were not related to egg laying performance, but rather to a different Ca metabolism, bone structure and body weight.

Dietary levels of $\mathrm{Ca}$ and $\mathrm{P}$ and the use of feed additives affected the biomechanical indicators of the tibia (Table 2). Reducing the levels of dietary $\mathrm{Ca}$ and $\mathrm{P}$ decreased the tibia breaking strength by $8.9 \%(P \leq 0.001)$, the yield load by $5.6 \%(P \leq 0.05)$ and tibia stiffness by $7.6 \%(P \leq 0.01)$. Similar tendency was observed for the bone breaking 


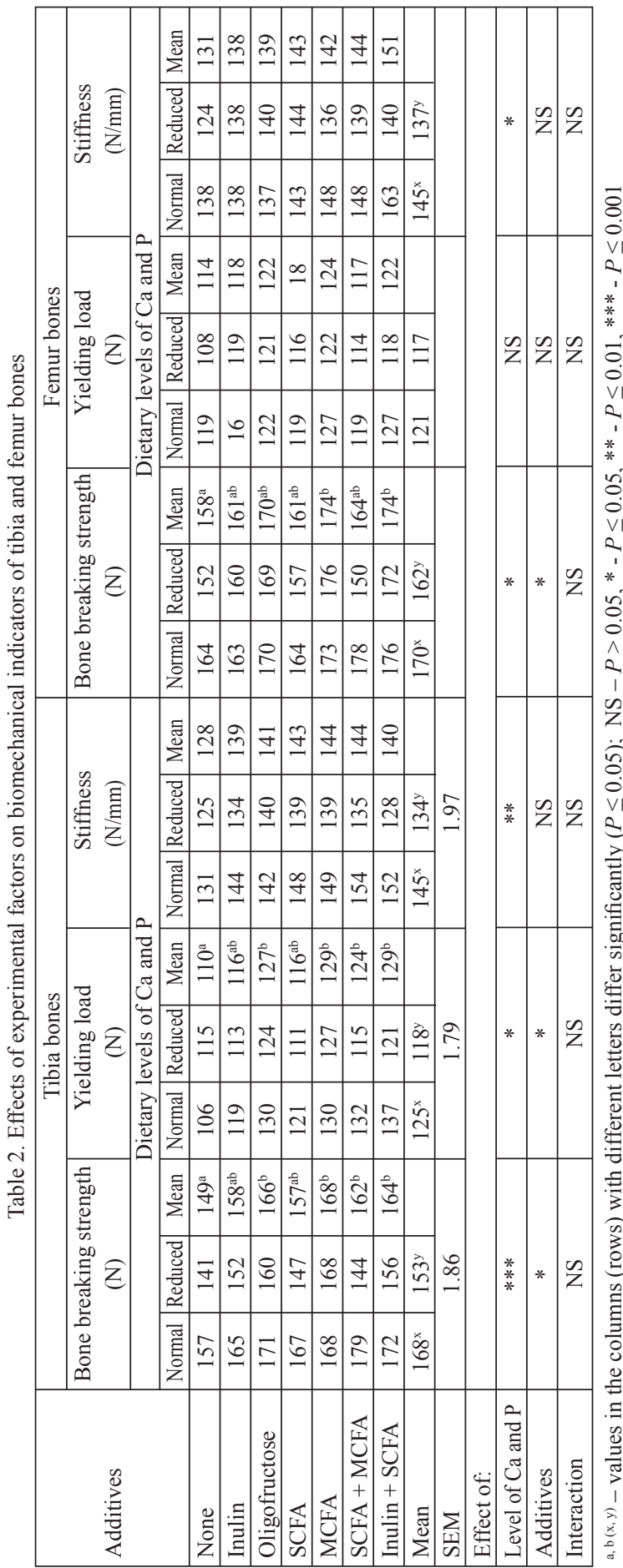

strength $(P \leq 0.05)$ and stiffness $(P \leq 0.05)$ of femur bones (Table 2). Diet with a lower level of $\mathrm{Ca}$ and $\mathrm{P}$ had a negative effect on geometrical indicators of tibias and femurs such as cortex thickness $(P \leq 0.05)$ and cross-section area $(P \leq$ 0.05 ), but had no effect on tibia and femur weight and length (Tables 3 and 4). The effect of dietary $\mathrm{Ca}$ level on hen bone quality was also observed by Schreiweis et al. (2003) who reported that tibia and humerus density, mineral content, bone breaking force and modulus of elasticity decreased as dietary $\mathrm{Ca}$ was lowered in the diet. Cheng and Coon (1990ab) found a linear increase in bone ash concentration and bone breaking strength in hens fed $\mathrm{Ca}$, in amounts increasing on a daily basis from 2.0 to $4.5 \mathrm{~g}$. A similar tendency for tibia breaking strength was observed when the dietary $\mathrm{Ca}$ concentration increased from 28 to $42 \mathrm{~g} / \mathrm{kg}$ (Narvaez-Solarte et al. 2006).

Some of the additives used had a positive effect on the biomechanical characteristics of bones. Hens fed diets with the addition of oligofructose, MCFA, SCFA + MCFA or inulin + SCFA had a significantly higher bone breaking strength and yield load of tibia than in the control group (Table 2). In the femurs, the positive influence of MCFA or the simultaneous addition of inulin + SCFA was found for breaking strength (Table 2). There were no significant effects of additives on the geometrical indicators of both bones (Tables 3 and 4). Lack of interaction between experimental factors (Tables 2, 3 and 4) indicates 


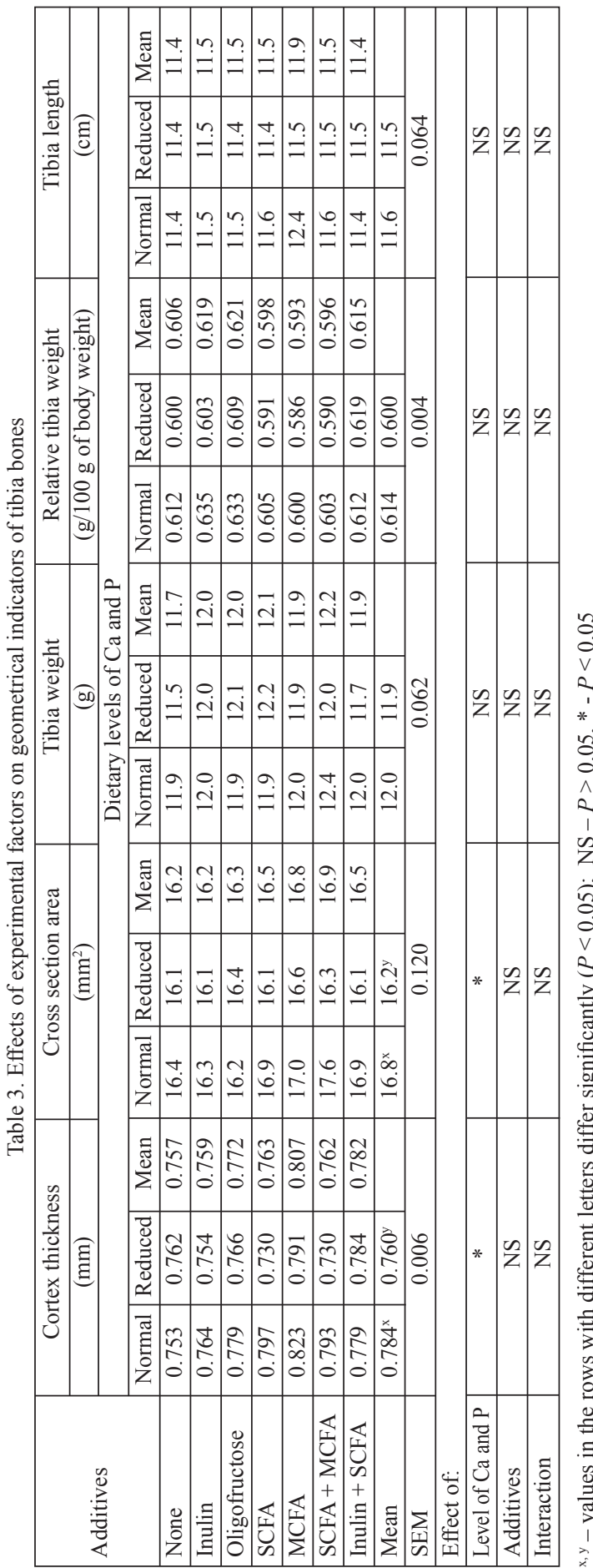

that efficacy of used feed additives in improving bone quality is not connected with the dietary level of $\mathrm{Ca}$ and $\mathrm{P}$.

Experimental data on the effect of prebiotic fructans or organic acids on the quality of bones in poultry are limited. Results corresponding to our findings were obtained by Chen and Chen (2004), who noted that supplementing the diet with $10 \mathrm{~g} / \mathrm{kg}$ of oligofructose or inulin increased the total ash, $\mathrm{Ca}$ and $\mathrm{P}$ in the tibia of layers. In molted hens, supplementation of alfalfa diet with fructooligosaccharides $(7.5 \mathrm{~g} / \mathrm{kg}$ of diet) prevented a decrease in tibia and femur breaking strength and in tibia mineral content during molting (Kim et al. 2006). The authors of this study have concluded that, probably due to their beneficial effect on $\mathrm{Ca}$ absorption, fructooligosaccharides have the potential to maintain bone strength, which is often reduced by structural bone loss during molting. In a study on rats, dehydrated chicory, a rich source of inulin, increased the distal bone mineral density and breaking load and was more effective in this effect than purified inulin (Demigne et al. 2008).

Based their work on a model study with ovariectomized rats, Zafar et al. (2004) indicated that protective effects of fructans on bone were established through increased $\mathrm{Ca}$ absorption and $\mathrm{Ca}$ balance, increased bone mineralization and decreased bone turnover rate. In an in vitro study, fructooligosaccharides increased the net transport of $\mathrm{Ca}$ in the small and large intestines of rats (Mineo et al. 2001). Kruger et al. (2003) reported that the effects of fructooligosaccharides with various degree of polymerization (DP) on $\mathrm{Ca}$ bioavailability and bone mineralization in rats were 


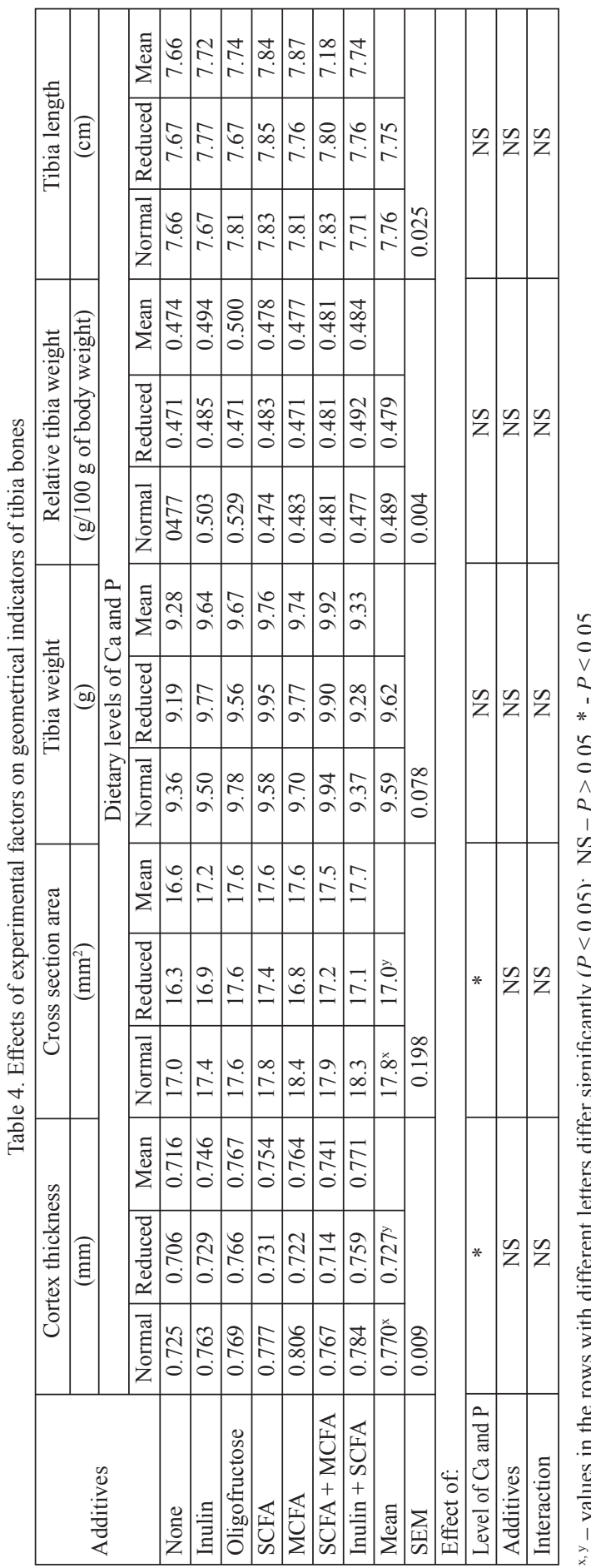

not the same. Long chain inulin $(\mathrm{DP}>23)$ increased the bone mineral density and bone mineral content in the femur and the spine to a considerably greater extent than oligofructose. According to Scholz-Ahrens et al. (2007), the mechanism of the positive effect of fructans on mineral utilization complex can be related to such factors as high solubility of minerals because of increased production of short chain fatty acids by probiotic bacteria through an increased supply with substrate (fructans), an alteration of intestinal mucosa and an increase of the absorption surface by beneficial effect of bacterial fermentation products on the proliferation of enterocytes, increased expression of $\mathrm{Ca}$ binding proteins, release of bone modulating factors, degradation of phytates by probiotic bacteria enzymes, and overall improvement of gut health.

In our study, the addition of MCFA, and the simultaneous addition SCFA + MCFA or SCFA + inulin had a beneficial effect on the selected biomechanical indicators of the tibia bones. This influence can be probably attributed to improved availability of $\mathrm{Ca}$ and $\mathrm{P}$ by virtue of a decrease in $\mathrm{pH}$ in the upper part of the intestine and the stimulating effect of organic acids on villus height, which was observed in broilers by Senkoylu et al. (2007). It has also been proposed that organic acids (citric acid) improved $\mathrm{Ca}$ availability by chelating $\mathrm{Ca}$ and reducing the formation of insoluble Ca-phytate-complexes (Boling et al. 2000).

Findings corresponding to our results were obtained by Nezhad et al. (2008) who indicated that tibia mineralization (ash content) in 64-week-old laying hens was 
increased after the addition of citric acid. The positive effect of citric acid on the bone crude ash was also found in broilers; however, there was no influence of malic acid or fumaric acid (Liem et al. 2008). Orban et al. (1993) found that the addition of ascorbic acid to the broilers' diet increased the femur breaking strength. In a study on pigs, Radcliffe et al. (1998) observed no effect of citric acid supplementation on bone breaking strength, but reported a tendency $(P<0.08)$ for a linear increase in bone ash content with an increasing content of acid in the diet. Abdel-Fattah et al. (2008) reported that chicks fed a diet supplemented with organic acids had significantly higher $\mathrm{Ca}$ and $\mathrm{P}$ blood concentration, which the authors attributed to the lowering of gut $\mathrm{pH}$ and the increase in the absorption of these macroelements. Dietary acetic acid increased the $\mathrm{Ca}$ absorption and $\mathrm{Ca}$ content of the femur of ovariectomized rats suggesting that this acid may reduce the bone turnover caused by ovariectomy and may be helpful in preventing osteoporosis (Kishi et al. 1999).

In conclusion, the results of this study indicate that selected feed additives with the mode of action to lower the $\mathrm{pH}$ of the diet and intestinal content could have a positive effect on the mechanical properties of tibia and femur bones in aged, highly producing laying hens. Significant improvement in bone quality was obtained by the use of oligofructose, medium chain fatty acids, short + medium chain fatty acids or inulin + short chain fatty acids.

\section{Acknowledgement}

The study was supported by the Ministry of Science and Higher Education (Project No. N N311 247033 ).

\section{References}

Abdel-Fattah SA, El-Sanhoury MH, El-Mednay NM, Abdel-Azeem F 2008: Thyroid activity, some blood constituents, organs morphology and performance of broiler chicks fed supplemental organic acids. Internat J Poult Sci 7: 215$222 \mathrm{http}: / /$ www.pjbs.org/ijps/fin1060.pdf

AOAC 1990: Officials methods of analysis. $15^{\text {th }}$ ed. Association of Official Analytical Chemists, Aarlington, VA, USA

Boling SD, Webel DM, Mavromichalis I, Parsons CM, Baker DH 2000: The effects of citric acid on phytate-phosphorus utilization in young chicks and pigs. J Anim Sci 78: 682-689 http://jas.fass.org/cgi/reprint/78/3/682

Chen YC, Chen TC 2004: Mineral utilization in layers as influenced by dietary oligofructose and inulin. Internat J Poult Sci 3: 442-445 http://www.scialert.net/pdfs/ijps/2004/442-445.pdf

Cheng TK, Coon CN 1990a: Effect of calcium source, particle size, limestone solubility in vitro, and calcium intake level on layer bone status and performance. Poult Sci 69: 2214-2219 http://www.ncbi.nlm.nih.gov/pubmed/2084678

Cheng TK, Coon CN 1990b: Sensitivity of various bone parameters of laying hens to different daily calcium intakes. Poult Sci 69: 2209-2213 http://www.ncbi.nlm.nih.gov/pubmed/2084677

Clark WD, Cox WR, Silversides FG 2008: Bone fracture incidence in end-of-lay high producing, noncommercial laying hens identified using radiographs. Poult Sci 87: 1964-1970 http://poultsci.highwire.org/cgi/reprint/87/10/1964

Delzenne NM, Aertssens J, Verplaetse H, Roccaro M, Roberfroid M 1995: Effects of fermentable fructooligosaccharides on mineral, nitrogen, and energy digestive balance in the rats. Life Sci 57: 1579-1587 http://www.ncbi.nlm.nih.gov/ pubmed/7564905

Demigne C, Jacobs H, Moundras C, Davicco MJ, Horcajada MN, Bernalier A, Coxam V 2008: Comparison of native or reformulated chicory fructans, or non-purified chicory, on rat cecal fermentation and mineral metabolism. Eur J Nutr 47: 366-374 http://www.springerlink.com/content/f886541572431p22/

Fleming RH 2008: Nutritional factors affecting poultry bone health. Proc Nutr Soc 67: 177-183 http://journals. cambridge.org/action/displayAbstract?fromPage= online\&aid $=1842860$

Gregory NG, Wilkins LJ 1989: Broken bones in domestic fowl: handling and processing damage in end-of-lay battery hens. Brit Poult Sci 30: 555-562 http:/www.informaworld.com/smpp/ftinterface?content=a784236151\&rt=0\&for mat=pdf

Janssen WMMA 1989: European Table of Energy Values for Poultry Feedstuffs. $3^{\text {rd }}$ ed. Working Group No. 2 of the European Branch, World's Poult. Sci. Assoc., Beekbergen, The Netherlands.

Jendral MJ, Korver DR, Church JS, Feddes JJR 2008: Bone mineral density and breaking strength of White Leghorns housed in conventional, modified, and commercially available colony battery cages. Poult Sci 87: 828-837 http:// ps.fass.org/cgi/reprint/87/5/828

Kim WK, Donalson LM, Mitchell AD, Kubena LF, Nisbey DJ, Ricke SC 2006: Effects of alfalfa and fructooligosaccharide on molting parameters and bone qualities using dual x-ray absorptiometry and conventional bone assays. Poult Sci 85: 15-20 http://ps.fass.org/cgi/reprint/85/1/15

Kishi M, Fukaya M, Tsukamoto Y, Nagasawa T, Takehana K, Nishizawa N 1999: Enhancing effect of dietary vinegar on the intestinal absorption of calcium in ovariectomized rats. Biosci Biotechnol Biochem 63: 905-910 http://www. jstage.jst.go.jp/article/bbb/63/5/63 905/ article 
Koreleski J, Świątkiewicz S 2004: Calcium from limestone meal and grit in laying hen diets - effect on performance, eggshell and bone quality. J Anim Feed Sci 13: 635-645

Kruger MC, Brown KE, Collet G, Layton L, Schollum LM 2003: The effect of fructooligosaccharides with different degree of polymerization on calcium bioavailability in the growing rat. Exp Biol Med 228: 683-688 http://www. ebmonline.org/cgi/reprint/228/6/683

Liem A, Pesti GM, Edwards Jr HM 2008: The effect of several organic acids on phytate phosphorus hydrolysis in broiler chicks. Poult Sci 87: 689-693 http://poultsci.highwire.org/cgi/reprint/87/4/689

Lutz T, Scharrer E 1991: Effect of short-chain fatty acids on calcium absorption by the rat colon. Experim Physiol 76: 615-618 http://ep.physoc.org/content/76/4/615.full.pdf

McCoy MA, Reilly GAC, Kilpatrick DJ 1996: Density and breaking strength of bones of mortalities among caged layers. Res Vet Sci 60: 185-186 http://www.ncbi.nlm.nih.gov/pubmed/8685544

Mineo H, Hara H, Kikuchi H, Sakurai H, Tomita F 2001: Various indigestible saccharides enhance net calcium transport from the epithelium of the small and large intestine of rats in vitro. J Nutr 131: 3243-3246 http://jn.nutrition.org/cgi/ reprint/131/12/3243

Morohashi T, Sano T, Ohta A, Yamada S 1998: True calcium absorption in the intestine is enhanced by fructooligosaccharide feeding in rats. J Nutr 128: 1815-1818 http://jn.nutrition.org/cgi/reprint/128/10/1815

Narvaez-Solarte W, Rostagno HS, Soares PR. Uribe-Velasquez LF, Silva MA 2006: Nutritional requirement of calcium in white laying hens from 46 to $62 \mathrm{wk}$ of age. Internat J Poult Sci 5: 181-184 http://www.scialert.net/pdfs/ ijps/2006/181-184.pdf

Newman S, Leeson S 1999: The effect of dietary supplementation with 1,25-dihydroxycholecalciferol or vitamin $\mathrm{C}$ on the characteristics of the tibia of older laying hens. Poult Sci 78: 85-90 http://poultsci.highwire.org/cgi/ reprint/78/1/85

Nezhad YE, Sis MN, Gholshani AA, Saedi Y, Aminvakili R 2008: The effects of combination of citric acid and microbial phytase on the concentration of some minerals of serum and parameters of mineralization of tibia in commercial laying hens. Asian J Anim Vet Adv 3: 375-380 http://www.scialert.net/pdfs/ajava/2008/375-380.pdf

Nzeusseu A, Dienst D, Haufroid V, Depresseux G, Devogelaer JP, Manicourt DH 2006: Inulin and fructooligosaccharides differ in their ability to enhance the density of cancellous and cortical bone in the axial and peripheral skeleton of growing rats. Bone 38: 394-399 http://linkinghub.elsevier.com/retrieve/pii/S8756328205003819

Ohta A, Ohtsuki M, Baba S, Adachi T, Sakata T, Sagaguchi E 1995: Calcium and magnesium absorption from the colon and rectum are increased in rats fed fructooligosaccharides. J Nutr 125: 2417-2424 http://jn.nutrition.org/cgi/ reprint $/ 125 / 9 / 2417$

Orban JI, Roland DA, Cummins K, Lovell RT 1993: Influence of large doses of ascorbic acid on performance, plasma calcium, bone characteristics, and eggshell quality in broilers and Leghorn hens. Poult Sci 72: 691-700 http://www. ncbi.nlm.nih.gov/pubmed/8479954

Radcliffe JS, Zhang Z, Kornegay ET 1998: The effects of microbial phytase, citric acid, and their interaction in a corn-soybean meal-based diet for weanling pigs. J Anim Sci 76: 1880-1886 http://www.animal-science.org/cgi/ reprint/76/7/1880

Rehman H, Rosenkranz C, Bohm J, Zentek J 2007: Dietary inulin affects the morphology but not the sodium dependent glucose and glutamine transport in the jejunum of broilers. Poult Sci 86: 118-122 http://ps.fass.org/cgi/ reprint/86/1/118

Rennie JS, Fleming RH, McCormack HA, McCorquodale CC, Whitehead CC 1997: Studies on effects of nutritional factors on bone structure and osteoporosis in laying hens. Brit Poult Sci 38: 417-424 http://www.ncbi.nlm.nih.gov/ pubmed/9347152

Riczu CM, Saunders-Blades JL, Yngvesson AK, Robinson FE, Korver DR 2004: End-of-cycle bone quality in whiteand brown-egg laying hens. Poult Sci 83: 375-383 http://ps.fass.org/cgi/reprint/83/3/375

Roberfroid MB, Cumps J, Devogelaer JP 2002: Dietary chicory inulin increases whole-body bone mineral density in growing male rats. J Nutr 132: 3599-3602 http://jn.nutrition.org/cgi/reprint/132/12/3599

Sacakli P, Sehu A, Ergun N A, Genc B, Selcuk Z 2006: The effect of phytase and organic acid on growth performance, carcass yield and tibia ash in quails fed diets with low levels of non-phytate phosphorus. Asian-Aust J Anim Sci 19: 198-202

Scholz-Ahrens KE, Ade P, Marten B, Weber P, Timm W, Asil Y, Gluer C-C, Schrezenmeir J 2007: Prebiotics, probiotics, and synbiotics affect mineral absorption, bone mineral content, and bone structure. J Nutr 137: 838S-846S http:// jn.nutrition.org/cgi/reprint/137/3/838S

Schreiweis MA, Orban JI, Ledur MC, Hester PY 2003: The use of densitometry to detect differences in bone mineral density and content of live White Leghorns fed varying levels of dietary calcium. Poult Sci 82: 1292-1301 http:// ps.fass.org/cgi/reprint/82/8/1292

Senkoylu N, Samli HE, Kanter M., Agma A 2007: Influence of a combination of formic and propionic acids added to wheat- and barley-based diets on the performance and gut histomorphology of broiler chickens. Acta Vet Hungarica 55: 479-490 http://www.akademiai.com/content/j1407r0761153575/

Świątkiewicz S, Koreleski J 2005: Effect of 25-hydroxycholecalciferol in the diet on the quality of bones in caged laying hens. Medycyna Wet 61: 814-817 http://medycynawet.edu.pl/streszczenia_2005/2005_07_24.html

Świątkiewicz S, Koreleski J 2007: Quality of egg shells and bones in laying hens fed a diet containing distillers dried grains with solubles. Medycyna Wet 63: 99-103 http://medycynawet.edu.pl/pdf2007/styczen/200701s00990103.pdf 
Takahara S, Morohashi T, Sano T, Ohta A, Yamada S, Sasa R 2000: Fructooligosaccharide consumption enhances femoral bone volume and mineral concentration in rats. J Nutr 130: 1792-1795 http://jn.nutrition.org/cgi/ reprint/130/7/1792

Webster AB 2004: Welfare implications of avian osteoporosis. Poult Sci 83: 184-192 http://ps.fass.org/cgi/ reprint/83/2/184

Whitehead CC, Fleming RH 2000: Osteoporosis in laying hens. Poult Sci 79: 1033-1041 http://ps.fass.org/cgi/ reprint/79/7/1033

Zafar TA, Weav CM, Zhao Y, Martin BR, Wastney ME 2004: Nondigestible oligosaccharides increase calcium absorption and suppress bone resorption in ovariectomized rats. J Nutr 134: 399-402 http://jn.nutrition.org/cgi/ reprint/134/2/399 